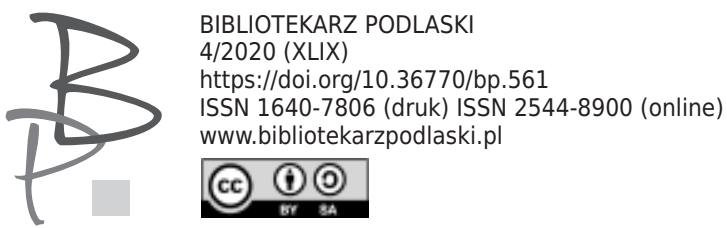

Szymon Trusewicz*

Uniwersytet w Białymstoku

https://orcid.org/0000-0002-4313-7256

\title{
Żywioł ziemi jako siła poezjotwórcza w wybranych utworach Eugeniusza Tkaczyszyna-Dyckiego
}

The element of the earth as a poetic force in selected works by Eugeniusz Tkaczyszyn-Dycki

Abstract: The article is an interpretation of works by Eugeniusz TkaczyszynDycki focused on the earth element as a poetic force. The motif of the stone is realized in this poetry as an image of the element, referring to the perception of existence in its cosmic and geological forms, as well as in the concrete and local form of the Bruśnie stone. This allows one to characterize the poetic imagination of Tkaczyszyn-Dycki as both inspired by the material properties of stone, as well as the culture and history of Lubaczowszczyzna. The poet can be characterized as creatively transforming the cultural, ecological and geological landscape of an autobiographical site.

Keywords: poetic imagination, Tkaczyszyn-Dycki, necros, material imagination, geopoetics.

Szymon Trusewicz - doktor nauk humanistycznych, literaturoznawca związany z Kolegium Literaturoznawstwa Uniwersytetu w Białymstoku. Autor artykułu: Wyobraźnia jako temat poezji i źródło kreatywności („Białostockie Studia Literaturoznawcze”2/2017). 
Wyobraźnia poetycka Eugeniusza Tkaczyszyna-Dyckiego swój zróżnicowany charakter zawdzięcza inspiracjom czerpanym z doświadczenia przyrody i lokalnego krajobrazu. Szczególnie interesujący wydaje się obecny w tej twórczości motyw kamienia, który wymaga interpretacji ze względu na funkcję poezjotwórczą. Zajmujący się wyobraźnią poetycką Gaston Bachelard zawarł w fenomenologicznych analizach żywiołów uwagi przydatne do interpretacji twórczości Tkaczyszyna-Dyckiego. Francuski filozof pisał: „W istocie wydaje mi się, że w dziedzinie wyobraźni da się ujawnić prawo czterech żywiołów, na podstawie którego można sklasyfikować różne kategorie wyobraźni materialnej, nawiązujące do ognia, powietrza, wody bądź ziemi”" W poezji Tkaczyszyna-Dyckiego można dostrzec obrazy poetyckie, które mają źródło we wszystkich materialnych żywiołach. Swoją uwagę skupiam na żywiole ziemi, aby wniknąć w istotę wyobraźni poetyckiej Tkaczyszyna-Dyckiego i zweryfikować tezę Andrzeja Niewiadomskiego, iż jest to „wykrystalizowany typ wyobraźni”’2. Charakter wyobraźni poetyckiej kształtuje się w sposób mniej lub bardziej świadomy za sprawą interakcji poetyckiego ,ja” z terytorium, w którym żyje i tworzy, a które inspiruje wyobraźnię twórczą. Interpretacja wyobraźni materialnej Tkaczyszyna-Dyckiego związana będzie z konkretem miejsca i charakterem lokalnego krajobrazu, którego ważnym elementem jest kamień i dlatego obraz kamienia rozpatrywać będę zarówno ze względu na jego materialne właściwości, jak i kontekst kulturowy i historyczny.

\section{Kamień bruśnieński}

Wśród kreowanych przez Tkaczyszyna-Dyckiego obrazów poetyckich inspirowanych żywiołem ziemi uwagę zwraca wyobrażenie kamienia, którego symbolika - bardzo szeroko reprezentowana w kulturze - współdzielona jest przez inne żywioły. Kamień oznacza praprzyczynę, istnienie, kości Matki-Ziemi; przypisuje mu się szereg odwołań religijnych: bóstwa, Boga, Chrystusa, Kościoła, św. Piotra, jak również pośrednio kojarzony jest z Chrystusem: próby, męczeństwa, śmierci³.

1 G. Bachelard, Woda i marzenia, przeł. A. Tatarkiewicz, [w:] tegoż, Wyobraźnia poetycka. Wybór pism, wybór H. Chudak, przedmowa J. Błoński, Warszawa 1975, s. 116.

2 A. Niewiadomski, Tańczyć kilka kości odstoniwszy, „Kresy” 1993, nr 13, s. 215.

3 Kamień, [hasło w:] W. Kopaliński, Stownik symboli, Warszawa 1990, s. 142. 
Wiersze Tkaczyszyna-Dyckiego, tematyzujące kamień bruśnieński, wprawdzie zawężają pole uniwersalnych odwołań, ale pozwalają na pogłębioną interpretację związaną z miejscem autobiograficznym poety ${ }^{4}$. Przypomnieć należy, że poezja Tkaczyszyna-Dyckiego ma autobiograficzny charakter ze względu na wielokrotnie komunikowaną przez poetę tożsamość piszącego i bohatera wierszy. Autor Kochanki Norwida w sposób bezpośredni mówi o zdarzeniach ze swojego życia, które wzbogaca o lokalne nazwiska i nazwy geograficzne. Opowieść o egzystencji poeta sytuuje na tle historii rodziny, umiejscawiając ją w rejonie byłego województwa przemyskiego, którego symboliczne centrum stanowi wieś Wólka Krowicka ${ }^{5}$. Wiersze przywołujące motyw kamienia bruśnieńskiego odsyłają do historii rzemieślniczej rodzimego regionu Tkaczyszyna-Dyckiego.

W odległości około trzydziestu kilometrów od Wólki Krowickiej znajdują się pozostałości po opuszczonej wsi Stare Brusno, słynnej na całą ziemię lubaczowską z bruśnieńskiego kamieniarstwa ludowego. Pobliskie złoża wapienia wykorzystywano nie tylko jako kamień budowlany, ale także do wytwarzania kamieni młyńskich i żarnowych. Z biegiem czasu zaczęto również sporządzać wyroby artystyczne: krzyże, figury przydrożne i nagrobki ${ }^{6}$. Wydobycie kamienia bruśnieńskiego sięga epoki późnego średniowiecza, zaś rozwój bruśnieńskiego kamieniarstwa datuje się na XVII wiek z apogeum przypadającym na przełom XIX i XX wieku7 . Gwałtowny upadek ośrodka nastąpił w latach 40. XX wieku w związku z drugą wojną światową i wysiedleniem ludności ukraińskiej ze Starego Brusna ${ }^{8}$. Najstarsze krzyże o rodowodzie wskazującym na szkołę ka-

4 Zob. M. Czermińska, Miejsca autobiograficzne. Propozycja w ramach geopoetyki, „Teksty Drugie" 2011, nr 5.

5 Zob. S. Trusewicz, Literacka mapa Eugeniusza Tkaczyszyna-Dyckiego, „Białostockie Studia Literaturoznawcze" 2015, $\mathrm{nr} 6$.

6 Ośrodek kamieniarski w Bruśnie, [hasło w:] Wikipedia, https://pl.wikipedia.org/wiki/ Ośrodek_kamieniarski_w_Bruśnie [24.11.2020 r.].

7 J. Mazur, Kamieniarstwo bruśnieńskie - genius loci ziemi lubaczowskiej, https://www. wilanow-palac.pl/kamieniarstwo_brusnienskie_genius_loci_ziemi_lubaczowskiej.html [6.06.2020 r.].

8 Tamże. Na temat kamieniarstwa bruśnieńskiego zob. Brusno. (Nie)istnienie w kamieniu, red. O. Solarz, Uście Gorlickie 2013; S. Lew, Ludowy ośrodek kamieniarski w Bruśnie, „Rocznik Przemyski” 1967, t. XI; Kamieniarstwo ludowe na roztoczu, oprac. A. Wójtowicz, http://teatrnn.pl/ leksykon/artykuly/kamieniarstwo-ludowe-na-roztoczu/ [6.06.2020 r.]. O analogicznym zjawisku kamieniarstwa józefowskiego w północnej części Roztocza zob. A. Szokaluk-Gorczyca, K. Gorczyca, Roztoczańskie kamienie pamięci. Ludowe kamieniarstwo józefowskie, Lublin 2014. 
mieniarstwa bruśnieńskiego wyróżniają się masywną budową, przypominającą w formie krzyż maltański.

Tkaczyszyn-Dycki posiada w swoim dorobku aż dwa utwory zatytułowane Piosenka o kamieniu bruśnieńskim. Jeden z nich został zamieszczony w zbiorze Przyczynek do nauki o nieistnieniu z 2003 roku, drugi opublikowano w 11 numerze „Twórczości” z 2016 roku9. Piosenka o kamieniu bruśnieńskim (2003) opowiada o ,przygranicznym małym miasteczku”:

w tym przygranicznym małym miasteczku są dwie księgarnie i dwa cmentarze do niedawna był tutaj jeden dom książki nieopodal cerkwi i jeden cmentarz przedwojenny z charakterystycznym kamieniem bruśnieńskim

i wymyślili że są dwie księgarnie w przygranicznym małym miasteczku (do którego bezspornie należę przez fakt urodzenia) by w pierwszej krzątali się ci co zmarli od nieczytania przejedzenia (do których nie zaliczam się

z racji uniwersyteckiego wykształcenia) w nowo otwartej zaś ci co spodziewają się ciągłych dostaw kultowych książek w kolorowych okładkach i tu jest pies pogrzebany mianowicie skąd je brać i nie ma już figur z kamienia bruśnieńskiego

(OW, s. 279 $)^{10}$

Poeta opisuje tu przestrzeń miasteczka, wskazując kilka interesujących go miejsc: dwie księgarnie, dwa cmentarze i ,jeden cmentarz przedwojenny z charakterystycznym kamieniem bruśnieńskim”. Chociaż poeta nie wymienia nazwy miejscowości, czytelnik znający biografię autora lub inne jego wiersze wie, że mowa o Lubaczowie, mieście położonym najbliżej rodzimej Wól-

9 W celu rozróżnienia obu wersji Piosenki o kamieniu bruśnieńskim w nawiasie zamieszczam rok wydania.

10 Cytaty z tomu wierszy zebranych Oddam wiersze $w$ dobre ręce (1988-2010), Wrocław 2010, zaznaczam skrótem OW. 
ki Krowickiej. Wskazuje na to określenie „przygraniczne małe miasteczko” i parenteza „do którego bezspornie należę przez fakt urodzenia”. Uszczypliwy ton, jaki przyjmuje mówiący w stosunku do opisywanego miejsca i samego siebie, wskazuje na niezadowolenie z przemian, jakie zachodzą w krajobrazie miejskim Lubaczowa. Frustrację poety odczytywać można jako efekt niedopasowania jego melancholijnej osobowości do warunków życia we współczesnym Lubaczowie, odmienionym przez potransformacyjne, wolnorynkowe przemiany i wykształcone w mieszkańcach konsumpcyjne zachowania. Konsumpcji łatwych treści i rozrywce służy jedna z księgarń znajdująca się w miasteczku, która powstała, aby „krzątali się ci co zmarli / od nieczytania przejedzenia". W drugiej natomiast gromadzą się czytelnicy literatury, która dzięki pozornej, wypracowanej przez kampanie reklamowe „kultowości” daje odbiorcom poczucie przynależności do kultury wyższej i zaspokaja pragnienie przynależności do elitarnego grona wysmakowanych konsumentów. Poeta w obu tych miejscach czuje się obco, nie odnajduje przynależności do żadnej z grup czytelniczych. O swoim ,wykształceniu akademickim”, które mogłoby być decydującym argumentem w dyskusji nad gustami czytelniczymi, Tkaczyszyn-Dycki mówi z przekąsem, dystansując się również wobec inteligencji. Odżegnuje się tym samym od wyższościowego, paternalistycznego wobec mieszkańców peryferii dyskursu. Swój sprzeciw wobec przemian w krajobrazie miejskim autor wypowiada z perspektywy osoby niedopasowanej, obcej, wprawdzie będącej „stąd”, ale ze względu na wykształcenie i zamieszkiwanie w innych miastach, będącej już „stamtąd”. Tkaczyszyn-Dycki wykorzystuje figurę pielgrzyma, znaną z jego innych utworów, w których pisał „tu jest moje legowisko gdzie indziej również mam siennik" (CIII, OW, s. 126). Jest to również perspektywa allogeniczna, zgodnie z rozpoznaniem Berthranda Westphala, referowanym przez Elżbietę Rybicką w artykule Auto/bio/geo/grafie, gdzie badaczka pisze o punkcie widzenia mówiącego:

[...] (p)ozwala [...] wychwycić sytuację, kiedy miejsca stają się obce lub własne, kiedy stawiają opór i wyobcowują, kiedy to, co "domowe" zaczyna ujawniać swą niepokojącą odmienność, destabilizować poczucie przynależności i wewnętrzny punkt widzenia ${ }^{11}$.

11 E. Rybicka, Auto/bio/geo/grafie, „Białostockie Studia Literaturoznawcze” 2013, nr 4, s. 19. 
Rybicka podkreśla podwójną funkcję allogenicznego punktu widzenia, służącego zarówno do autoprezentacji, jak i tworzenia imagologii przestrzennej ${ }^{12}$. Puenta Piosenki o kamieniu bruśnieńskim (2003) wskazuje, że mówiący pragnie wyrazić tęsknotę za rzeczywistością sprzed zmian w krajobrazie miasteczka. Mówi on w ostatniej strofie wiersza - pozornie bez związku o książkach w kolorowych okładkach: „mianowicie skąd je brać i nie ma już figur z kamienia // bruśnieńskiego". Przerzutnia ostatniego słowa uwypukla ból po stracie ważnego dla regionu lubaczowszczyzny dziedzictwa ludowej twórczości artystycznej i użytkowej, jaką tworzyli bruśnieńscy kamieniarze. Zaznaczony zostaje kontrast pomiędzy Wólką Krowicką współczesną, czyli miasteczkiem z dwiema komercyjnymi księgarniami, a Wólką Krowicką dawną. Przeszłość przywołuje jedynie przedwojenny cmentarz z figurami bruśnieńskich kamieniarzy, wyraźnie bliższy mówiącemu ze względu na estetykę, ale również ze względu na jego melancholijne usposobienie. Poeta przyglądając się lokalnemu krajobrazowi chętniej dostrzega pamiątki przeszłości, szczególnie te o funeralnym charakterze, jak właśnie nagrobki wykonanie z kamienia bruśnieńskiego. Stanowią one o tożsamości regionu, jak też o tożsamości samego poety. Trudno przypuszczać, że księgarnie, nawet dwie, pozwolą na stworzenie w miasteczku równie ważnych zjawisk kulturowych, jak bruśnieńskie rzeźby.

Drugi wiersz, zatytułowany Piosenka o kamieniu bruśnieńskim (2016), opublikowany został trzynaście lat później, choć zaznaczyć trzeba, że sygnują go anachronizujące miejsce i data „Olsztyn, 9 I 1989”:

twoje ręce nie zbudują domu

twoje usta nie zbudują wierszy

choć będziesz się przykładał

krzycząc i będziesz się udzielał

milcząc („nawet nie zauważysz

jak wokół nas wyrośnie

cmentarz przychylny tylko dla siebie

i tylko dla ciebie") 


\author{
każdy cmentarz unicki pozostaje \\ otwarty dla Dyckich i każdy \\ kamień bruśnieński rozpoznam \\ z daleka bo to mój kamień \\ którego wszakże nie udźwignąłem \\ w poezji nie wszystko można \\ unieść choć będziesz się przykładał \\ krzycząc i będzie się udzielał'13
}

W wierszu mowa o tęsknocie za przeszłością, w czym przypomina wcześniejszą wersję Piosenki o kamieniu bruśnieńskim (2003). Tkaczyszyn-Dycki koncentruje się jednak bardziej na roli poety i ograniczeniach poetyckiego języka. W wierszu tym znacznie silniej niż w Piosence o kamieniu bruśnieńskim (2003) odczuwalna jest atmosfera smutku i rozczarowania samym sobą, wynikająca z nieudanych prób zbudowania domu-wiersza, przestrzeni stałej i bezpiecznej. Ciężarem, z którym zmaga się Tkaczyszyn-Dycki, jest konieczność ograniczenia się w poetyckiej opowieści do wybranych faktów z dziejów regionu. Kamień bruśnieński symbolizuje tu historię Lubaczowszczyzny, pełną dramatycznych zdarzeń ${ }^{14}$. Widok kamieni bruśnieńskich, stanowiących ostatnie wytwory regionalnej szkoły kamieniarskiej, przypomina o cierpieniach ludności wywołanych przez wielką historię, agresję i przemoc. Tkaczyszyn-Dycki czuje moralny obowiązek ,uniesienia”, a więc odniesienia się w swojej poezji do historii miejsca peryferyjnego, marginalizowanego, takiego jak Stare Brusno.

Melancholijną atmosferę Piosenki o kamieniu bruśnieńskim (2016) buduje w dużej mierze kreowana przestrzeń cmentarza oraz w aspekcie stylistycz-

13 E. Tkaczyszyn-Dycki, II. Piosenka o kamieniu bruśnieńskim, „Twórczość” 2016, nr 11 (LXXII), s. 4.

14 Źródeł negatywnych doświadczeń mieszkańców regionu można szukać w ogólnej dynamice relacji międzyludzkich, które w poezji Tkaczyszyna-Dyckiego nie pozostają wolne od ksenofobii i nacjonalizmu. Jednak w relacjach tych odbicie mają również historyczne konflikty Polski i Ukrainy, które wywarły wpływ na społeczność, o której pisze poeta: wojna polsko-ukraińska, Druga Wojna Światowa, Rzeź Wołyńska. Dodać do tego należy powojenną akcję przesiedleńczą „Wisła”. Kontekst tych wydarzeń jest dla poezji Tkaczyszyna-Dyckiego kluczowy, bo dotyczą one bezpośrednio jego rodziny. Wywarły również wpływ na charakter relacji międzyludzkich, naznaczając je przemocą, agresją i nieufnością. 
nym nagromadzenie przeczeń, które odmalowują w języku psychiczny portret jednostki zrezygnowanej i przytłoczonej niepowodzeniami. Cała energia, którą poeta wkłada w twórczą aktywność, zostaje przejęta przez rozrastający się - na wzór żywego organizmu - cmentarz. Obraz rozwijającej się nekropolii epatuje witalną siłą, w przeciwieństwie do wizji nieefektywnej pracy poety. Tkaczyszyn-Dycki, pisząc o rosnącym „wokół nas” cmentarzu, przedstawia go jako mur oddzielający podmiot od świata, twór pochłaniający wszystkie wysiłki poety. Kreując cmentarz na wzór rozwijającego się lub, akcentując jego przestrzenny charakter, rozrastającego się kosztem ludzkich śmierci organizmu, poeta mówi o tragizmie i ironii ludzkiej egzystencji. Słowa mówiące o „otwartości” cmentarza na „każdego” Dyckiego odnosić trzeba do samego poety, którego twórczość dotyczy tematyki funeralnej i historii własnej rodziny. Jest to jednocześnie uwaga uniwersalna, przypomnienie o sile rozpadu, która prowadzi do śmierci człowieka. Trwogę tego momentu poeta równoważy pozytywnym aspektem rozrostu nekropolii, która karmi inne organizmy, co zaświadcza o nieprzerwanym ciągu życia. Przedstawia cmentarz jako miejsce przepływu sił witalnych.

Ewa Domańska w pracy Nekros. Wprowadzenie do ontologii martwego ciała postrzega cmentarz jako miejsce metamorfoz nekrotycznych. Definiując tytułowe pojęcie badaczka koncentruje się na różnych formach sprawczości, a sam Nekros charakteryzuje jako żywioł transformujący materialne szczątki. Pisze ona: „U postaw idei Nekrosu stoi teoria nekro-witalizmu, tj. powstawania życia z materii martwej”"15. Cmentarz ze względu na zachodzące tam metamorfozy nekrotyczne stanowi miejsce powstawania nowych form istnienia martwego ciała i szczątków. Domańska postrzega tę przestrzeń nie tylko jako element krajobrazu kulturowego czy ekologiczno-kulturowego, ale jako zbiór specyficznych ekosystemów i geosystem ${ }^{16}$. Siebie samego Tkaczyszyn-Dycki charakteryzuje jako pozostającego w łączności ze światem żywych i zmarłych, co ponownie odczytywać można jako wyraz wyobcowania.

W obu Piosenkach kamień bruśnieński ewokuje stratę. W pierwszym utworze (2003) Tkaczyszyn-Dycki za pośrednictwem symboliki kamienia mówi o upływającym czasie i przemianach w krajobrazie miasteczka. W dru-

15 E. Domańska, Nekros. Wprowadzenie do ontologii martwego ciała, Warszawa 2017, s. 7.

16 Tamże, s. 215-217. 
gim wierszu (2016) pisze o ubywających siłach życiowych i swoich twórczych porażkach, jakie pojawiły się podczas prób zbudowania bezpiecznej przestrzeni domu-wiersza ${ }^{17}$. Mowa zatem o tęsknocie, której charakter jest zmienny i rozproszony w niejasno zarysowanej przeszłości, w czym ujawnia się melancholijny charakter poezji Tkaczyszyna-Dyckiego. Alina Świściak melancholię Tkaczyszyna-Dyckiego postrzega przez pryzmat ,pustej obecności” obiektów wypełniających jego poetycki świat: „Przypomina on (ów świat) miejsce wymarłe lub miejsce umierania; jest tym, co pozostało po zmarłych, lub przestrzenią, w której - i z której (nieustannie, wielokrotnie) - odchodzą żywi"18. Poeta, dostrzegając element ewokujący rozpad i umieranie, zwielokrotnia jego obecność, czyniąc z niego często motyw dominujący opis przestrzeni. W tej funkcji występuje w powyższych wierszach kamień bruśnieński, przypominając swoją pustą obecnością o świecie minionym.

\section{Kamień pełen pokarmu}

Przyglądając się obu Piosenkom o kamieniu bruśnieńskim, należy spojrzeć na kamień jako przedmiot poezjotwórczy i zapytać, czy materialne właściwości żywiołu inspirują Tkaczyszyna-Dyckiego wyłącznie do melancholijnych refleksji. Wytwory kamieniarzy ze Starego Brusna stanowią w Piosenkach o kamieniu bruśnieńskim symbol straty i tęsknoty. Obecność krzyży czy nagrobków wykonanych z kamienia bruśnieńskiego przypomina o dramatycznych czasach drugiej wojny światowej i nagłego końca tej szkoły kamieniarskiej. Skojarzenia związane z przemijaniem i rozpadem nie są jedynymi, jakie

17 Twórczość Tkaczyszyna-Dyckiego można interpretować jako formę praktykowania przestrzeni przez pryzmat użytego przez niego porównania ,poezji jako miejsca na ziemi”. W wielu wierszach Tkaczyszyn-Dycki postrzega poezję jako ucieczkę od rzeczywistości, jednak charakter jego poetyki zamieszkiwania wskazuje na artystyczny sposób egzystowania w realnym świecie. W efekcie rozważania odwołujące się do kategorii „zamieszkiwania w tekście” przedstawiają poiesis Tkaczyszyna-Dyckiego jako proces oscylowania między realnym a wyobrażonym za pośrednictwem tropów. Źródła inspiracji poetyk związanych z zamieszkiwaniem przestrzeni jako praktyką twórczą należy szukać w słowach Hölderlina „Pełen zasług, lecz poetycko mieszka człowiek na tej ziemi”, a ich filozoficznego rozwinięcia w esejach Martina Heideggera Budować, mieszkać myśleć. Zob. M. Heidegger, Budować, mieszkać, myśleć: eseje wybrane, wybrał, oprac. i wstępem opatrzył K. Michalski, przeł. K. Michalski, Warszawa 1977; E. Konończuk, Poetyka zamieszkiwania, „Poznańskie Studia Polonistyczne. Seria Literacka” 2017, nr 30; P. Paszek, Archipelag odłogi. Fragment do przyszłej geopoetyki Śląska Cieszyńskiego, „Anthropos?” 2014, nr 23.

18 A. Świeściak, Śmiertelne sublimacje. Eugeniusz Tkaczyszyn-Dycki, [w:] tejże, Melancholia w poezji polskiej po 1989 roku, Kraków 2010, s. 148. 
koncentruje w sobie poetycki obraz kamienia. Kamień bruśnieński to konkretna, związana z miejscem autobiograficznym Tkaczyszyna-Dyckiego realizacja motywu kamienia, jednak w wielu wierszach poety pojawia się on w swojej archetypicznej formie. Szczególnie interesujący potencjał znaczeniowy niesie symbolika kamienia jako pokarmu. Poeta posługuje się kilkukrotnie frazą „kamień pełen pokarmu”, umieszczając ją w różnych kontekstach. Wstrzymuję się z ich przywołaniem, aby opisać ewokowane przez samą frazę wyobrażenie ${ }^{19}$.

Obraz poetycki kamienia pełnego pokarmu stanowi przeciwieństwo melancholijnych skojarzeń w Piosence o kamieniu bruśnieńskim (2016), wskazujących na symbolikę utraty. W wyobrażeniu kamienia pełnego pokarmu mowa o żywiole sycącym wyobraźnię, przekazującym poecie siłę, inspirującym do eksploracji własnego ,ja”. Wrażenia te wywoływane są nie tylko przez materialne właściwości kamienia, ale również jego bliskość z ziemią rozumianą jako arché. Ziemia stanowi w tym odczytaniu praprzyczynę biologiczną, źródło energii i życia, ale również wyobraźni, inspirując poetę swoim kształtem, fakturą, zapachem. Odwieczny kamień, zmieniający jedynie swoje formy, fascynuje swoją tajemniczością i inspiruje do porzucenia ograniczonej perspektywy ludzkiego trwania. Widoczne jest to w wierszu Kamień peten pokarmu:

łąki wam oddaję i rzeki wam powierzę
niechaj od nowa wylewają się z koryta
każdej nocy: „kiedy ty idziesz do niego
i kiedy on idzie do ciebie” oddaję wam

rzeki co do jednej Wisznię Sołotwę

Lubaczówkę i kwiatu wam nie odmówię

odkąd jestem kwiatem wyniesionym

ze snu: „kiedy ty idziesz do niego

19 Wyrażenie „kamień pełen pokarmu” ma swoje konotacje biblijne, gdyż w tradycji chrześcijańskiej kamień symbolizuje przeciwieństwo pożywienia: „Albo który z was człowiek, którego jeśliby syn jego prosił o chleb , poda mu kamień?” (Mt, 7, 9). Władysław Kopaliński podaje w Słowniku symboli, że kamień jest nazywany bochenkiem św. Szczepana, który poniósł śmierć przez ukamieniowanie (Kamień, [hasło w:] W. Kopaliński, Słownik symboli, s. 144). 
i kiedy on idzie do ciebie" porzucam

was dla własnego ognia co się

w ręku staje jeszcze większym ogniem

w moim ręku wszystko się powiększa

i zaokrągla w moich ustach wszak kamień

staje się pełniejszy odkąd jestem

kamieniem coraz bardziej pożywnym z dna

rzeki wyniesionym z głębokiego snu

(CLXXXVI. Kamień pełen pokarmu, OW, s. 217)

Tkaczyszyn-Dycki, inspirowany wyobrażeniem przedwiecznej ziemi, mówi o sobie jako o kamieniu wydobytym z dna rzeki, a jednocześnie z głębokiego snu, rozpatrując swoje istnienie jako rodzaj continuum. Forma kamienia zdaje się być jedną z ostatnich w łańcuchu przemian ,ja”, które przyjmuje również postać kwiatu, wody i ognia. Metaforyka używana przez poetę przynosi „kosmiczny” i przedwieczny obraz podróży podmiotu, zaskakujący w przypadku poety zwykle kojarzonego z tożsamościową czy metafizyczną refleksją nad podmiotowością, formowaną przez kulturę i historię.

Powyższy wiersz każe dostrzec w Tkaczyszynie-Dyckim geopoetę w znaczeniu, jakie interpretując pisarstwo Kennetha White'a nadała Elżbieta Konończuk. Badaczka akcentuje ruch podmiotu zarówno w przestrzeni geograficznej, jak i w mentalnej przestrzeni myśli, by określić wyobraźnię White’a za pomocą figury „poza”. Jest to jednocześnie „poeta-kosmograf”, badający głębiny swojej własnej wyobraźni i dziejów planety, jak i perypatetyk, przekraczający granice mniej i bardziej realnych krain ${ }^{20}$. Tkaczyszyn-Dycki chętnie posługuje się obrazem pielgrzyma czy obcego, w związku z czym jego wyobraźnię przestrzenną również można charakteryzować jako odwołującą się do figury „poza”. Obraz poetycki kamienia pełnego pokarmu zaświadcza o sprawczej roli wyobraźni materialnej, o której Bachelard mówił, że rodzą się z niej:

20 E. Konończuk, Poetyka przestrzeni geograficznej wedlug Kennetha White'a, „Białostockie Studia Literaturoznawcze” 2015, nr 6. 
[...] obrazy bezpośrednio związane z materią. Nazwę swą zawdzięczają oczom, lecz poznajemy je dotykiem. Jakaś dynamiczna siła włada nimi, nadaje im kształt, uskrzydla. Te obrazy związane z materią stanowią treść naszych marzeń substancjalnych, głębinowych, które śnimy odrzucając formy nietrwałe i przemijające, płonne obrazy i to wszystko, co dzieje się na powierzchni ${ }^{21}$.

Wyobraźnia poetycka Tkaczyszyna-Dyckiego bez wątpienia poddaje się żywiołowi ziemi, który otwiera jego twórczość na perspektywę kosmiczną. Pozwala to poecie przekroczyć kulturowy i historyczny horyzont w refleksji nad własnym ,ja”, jak i miejscem, w którym żyje, pogłębiając (nomen omen) jego znaczenie.

\section{Poezjotwórcza siła kamienia}

Ze względu na melancholijny charakter poezji Tkaczyszyna-Dyckiego elementem centralnym, wokół którego organizuje on opis swojego świata, stają się nagrobki i cmentarze. Piosenka o kamieniu bruśnieńskim (2016) jest wierszem metapoetyckim, o pesymistycznym wydźwięku, skupiającym się na opisie niepowodzeń i trudności twórczych. Słowa wypowiadane w ostatniej strofie pozwalają jednak dostrzec w utworze refleksję przełamującą negatywny nastrój. Wyrozumiałe wobec samego siebie „,w poezji nie wszystko można / unieść" ukazuje Tkaczyszyna-Dyckiego jako twórcę zdającego sobie sprawę z siły jaką ewokuje obraz kamienia. Kamień stanowić może ciężar i symbol śmierci, ale jest to również, jak wskazuje Bachelard, żywioł mocy i energii twórczej. Filozof w zbiorze Ziemia, wola i marzenia snując refleksję nad twardością jako inspiracją wyobraźni literackiej stwierdza: ,[...] twardość rzadko bywa przedmiotem doświadczenia, niemniej jest ona źródłem nieprzeliczonych obrazów. Każdy, najbłahszy nawet kontakt z twardością pobudza wyobraźnię do swoistej pracy"21.

Interpretacja, którą rozwija Bachelard, akcentuje skojarzenia twardości z ludzką siłą, ale również gniewem, pychą i pogardą. Przywołując obraz sękatego drzewa w prozie Virginii Woolf, pisze: „Mocarny pień, twarde korzenie - oto ośrodek, wokoło którego organizuje się krajobraz, wokoło którego snuje

21 G. Bachelard, Woda i marzenia, s. 114.

22 G. Bachelard, Metaforyka twardości, [w:] tegoż, Wyobraźnia poetycka, s. 224. 
się wątek obrazu literackiego - komentowanego świata"23. Skoncentrowanie na przeszłości prowadzi Tkaczyszyna-Dyckiego ku tematyce śmierci, utraty i rozpadu, ale również ku rozumieniu ziemi jako zasadzie sprawczej. W Piosence o kamieniu bruśnieńskim (2016) moc ewokowana przez kamień skłania poetę do stwierdzenia: „kamień bruśnieński rozpoznam / z daleka bo to mój kamień”, czym zaświadcza o bliskości z żywiołem ziemi. Nie oznacza to jednak, że linia podziału pomiędzy śmiercią i życiem, rozpadem i wzrostem pokrywa się z podziałem na kulturowy i naturalny krajobraz. Poetycki potencjał kamienia bruśnieńskiego skłania do uwzględnienia umacniającej się w dyskursie nowej humanistyki tendencji do odrzucania tej opozycji. Kamień przyjmujący formę nagrobka czy pomnika nie zostaje nigdy odebrany przyrodzie, zachowując swoje właściwości i znaczenia związane z żywiołem ziemi. Widok kamienia nagrobnego pochylającego się, zapadającego w ziemię, kruszejącego czy pokrywanego mchem przypomina o jego przyrodniczym pochodzeniu. Również cmentarz w swojej charakterystyce nie poddaje się schematycznym rozróżnieniom kultura-natura, śmierć-życie. Cmentarz to miejsce, gdzie ciało poddane rozkładowi daje życie nowym organizmom, a w doktrynie chrześcijańskiej otwiera drogę do życia wiecznego. „Węzłowy” charakter przestrzeni cmentarza, będącego łącznikiem pomiędzy zmarłymi i żywymi, widoczny jest również z perspektywy psychologii, o czym pisze Maria Lewicka:

Każdy nagrobek staje się konsekwencją nie tylko indywidualnych losów jednostki, ale całej społeczności, której historia utrwalona jest w pomnikach, epitafiach, symbolach. Przestrzeń sepulkralna okazuje się więc swego rodzaju kotwicą łączącą mieszkańców miast z ich własną przeszłością, wzbudzając poczucie trwałości więzi w obrębie przestrzeni niepodlegającej szybkim przemianom. należący do wspólnoty cmentarz miejski nie jest w tradycji polskiej przestrzenią zapomnianą czy ekskludowaną. Wręcz przeciwnie, staje się sceną, na której rozgrywa się miejski spektakl życia codziennego ${ }^{24}$.

23 Tamże, s. 229.

24 M. Lewicka, Dwa miasta - dwa mikrokosmosy. Wrocław i Lwów w pamięci swoich mieszkańców, [w:] My Wrocławianie. Społeczna przestrzeń miasta, red. P. Żuk, J. Pluta, Wrocław 2006, s. 82-83. 
W Piosence o kamieniu bruśnieńskim (2016) Tkaczyszyn-Dycki dostrzega paradoksalny status cmentarza, ukazując go jako żywy, rozrastający się organizm, który pochłania życia, ale jednocześnie stanowi węzeł łączący świat żywych i umarłych. W świetle powyższych uwag kamień bruśnieński jawi się jako obraz poetycki posiadający duży i zróżnicowany potencjał poezjotwórczy. Ponownie przydatne w zrozumieniu wyobraźni poetyckiej TkaczyszynaDyckiego stają uwagi Domańskiej, która Nekros definiuje jako żywioł:

Nekros manifestuje życie nieodłączne od materii, życie jako rodzaj związku. To zarówno realny, materialny i dynamiczny byt, jak i proces stałego przekształcania się wskazujący nieograniczony potencjał zmian, a przede wszystkim przemian. [...] Nekros zawsze jednak symbolizuje przenikanie się i przekraczanie tego, co ludzkie i nie-ludzkie, organiczne i nieorganiczne, a przede wszystkim tego, co żywe i martwe ${ }^{25}$.

Świat poetycki Tkaczyszyna-Dyckiego zostaje przez poetę zróżnicowany ze względu na formy istnienia, podobnie jak wyobraźnia twórcza, która jawi się jako lokalna i kosmiczna zarazem. Ludzki los poeta rozpatruje w kontekście miejsca autobiograficznego, skupiając się na kulturze i historii, tak jak w przypadku kamieniarzy ze Starego Brusna. Obraz kamienia jest na tyle inspirujący, że otwiera autora na inną, nie-ludzką perspektywę biologicznego i geologicznego życia, a poezjotwórcza siła żywiołu inspiruje Tkaczyszyna-Dyckiego do refleksji nad własną podmiotowością. W związku z tym twórcę można scharakteryzować jako wykorzystującego figurę „poza” melancholijnego geopoetę.

\section{Bibliografia}

Bachelard G., Wyobraźnia poetycka. Wybór pism, wybór H. Chudak, przeł. H. Chudak, A. Tatarkiewicz, przedmowa J. Błoński, Warszawa 1975.

Brusno. (Nie)istnienie w kamieniu, red. O. Solarz, Uście Gorlickie 2013.

25 E. Domańska, Nekros, s. 68. 
Czermińska M., Miejsca autobiograficzne. Propozycja w ramach geopoetyki, „Teksty Drugie" 2011, nr 5.

Domańska E., Nekros. Wprowadzenie do ontologii martwego ciała, Warszawa 2017.

Heidegger M., Budować, mieszkać, myśleć: eseje wybrane, wybrał, oprac. i wstępem opatrzył K. Michalski, przeł. K. Michalski, Warszawa 1977.

Konończuk E., Poetyka przestrzeni geograficznej według Kennetha White’a, „Białostockie Studia Literaturoznawcze" 2015, nr 6.

Konończuk E., Poetyka zamieszkiwania, „Poznańskie Studia Polonistyczne. Seria Literacka" 2017, nr 30.

Kopaliński W., Słownik symboli, Warszawa 1990.

Lew S., Ludowy ośrodek kamieniarski w Bruśnie, „Rocznik Przemyski” 1967, t. XI. Kamieniarstwo ludowe na roztoczu, oprac. A. Wójtowicz, http://teatrnn.pl/leksykon/ artykuly/kamieniarstwo-ludowe-na-roztoczu/ [24.11.2020 r.].

Lewicka M., Dwa miasta - dwa mikrokosmosy. Wrocław i Lwów w pamięci swoich mieszkańców, [w:] My Wrocławianie. Społeczna przestrzeń miasta, red. nauk. P. Żuk, J. Pluta, Wrocław 2006.

Mazur J., Kamieniarstwo bruśnieńskie - genius loci ziemi lubaczowskiej, https://www. wilanow-palac.pl/kamieniarstwo_brusnienskie_genius_loci_ziemi_lubaczowskiej. html [24.11.2020 r.].

Niewiadomski A., Tańczyć kilka kości odsłoniwszy, „Kresy” 1993, nr 13.

Ośrodek kamieniarski w Bruśnie, hasło w: Wikipedia, https:// pl.wikipedia.org/wiki/ Ośrodek_kamieniarski_w_Bruśnie [24.11.2020 r.].

Paszek P., Archipelag odłogi. Fragment do przyszłej geopoetyki Śląska Cieszyńskiego, „Anthropos?” 2014, nr 23.

Rybicka E., Auto/bio/geo/grafie, „Białostockie Studia Literaturoznawcze” 2013, nr 4, s. 19.

Szokaluk-Gorczyca A., Gorczyca K., Roztoczańskie kamienie pamięci. Ludowe kamieniarstwo józefowskie, Lublin 2014.

Świeściak A., Melancholia w poezji polskiej po 1989 roku, Kraków 2010.

Tkaczyszyn-Dycki E., II. Piosenka o kamieniu bruśnieńskim, „Twórczość" 2016, nr 11 (LXXII).

Tkaczyszyn-Dycki E., Oddam wiersze w dobre ręce (1988-2010), Wrocław 2010.

Trusewicz S., Literacka mapa Eugeniusza Tkaczyszyna-Dyckiego, „Białostockie Studia Literaturoznawcze" 2015, nr 6. 